Bogotá, Colombia

lukestephentaylor@gmail.com Cite this as: BMJ2020;371:m3938 http://dx.doi.org/10.1136/bmj.m3938 Published: 19 October 2020

\section{Covid-19: Venezuela's doctors refuse to be gagged}

\section{Overworked, overstretched, and in grave danger, Venezuela's doctors remain defiant to government persecution in one of the worst affected areas in the pandemic, writes Luke Taylor}

\section{Luke Taylor freelance journalist}

Alcohol, blood tests, basic medicine, laboratory supplies, ventilators-the list of shortages a

Venezuelan doctor faces while working 24 hour shifts in an emergency ward in one of the country's principal public hospitals is long and punctuated by weary sighs of frustration.

Many of the basic services that are available at the hospital come with a caveat: antibiotics can be administered and radiographs taken but they are unaffordable to most patients; the ambulances function but are not running owing to nationwide petrol shortages.

“There isn't even paper so we can't keep the patients' medical history," an internist, who preferred not to be named, told The BMJ.

Shortages of the most basic medical supplies have become an alarming norm in Venezuela's hospitals in recent years as the country has fallen into economic and political turmoil. Doctors have relied on donations from non-governmental organisations like the International Red Cross and the basics they can afford to buy themselves, such as cleaning alcohol and tools, to plug the gap.

Then the pandemic arrived.

Hospital staff, already overworked, and supplies, already lacking, have become stretched like never before by the influx of covid-19 patients.

Shortages of personal protective equipment (PPE) are putting health workers in peril. At least 220 had died with covid-19 as of 8 October-around one a day-says Medicos Unidos Venezuela, an advocacy group of doctors monitoring the crisis. ${ }^{1}$

“It's like working in a warzone," says the internist. But like most Venezuelan healthcare workers it's a choice of risking contracting the illness or not putting food on the table.

The internist worked day shifts in a clinic dedicated to covid-19 patients to supplement the $\$ 23$ (£18; €19) she earns a month working 24 hour shifts in an emergency ward. The money helped support her two children as hyperinflation, estimated to be over $4000 \%$, made food more expensive every day. ${ }^{2}$

But fearing she would be the latest doctor added to the quickly growing list of those infected in the clinic, she resigned last week.

"A lot of my colleagues have quit and many have gotten sick, every time I went there were less of us," the internist says. "It's the fear, the fear that not only we will get infected, but that we will pass it on to our family members."

\section{The crisis before the crisis}

Around half of the world's covid-19 infections have been recorded in Latin America. Though few countries have been spared its devastation, arguably none was worse prepared for its arrival than Venezuela.

Despite holding the biggest oil reserves in the world, the country's economy has been in freefall in recent years. Some nine million Venezuelans are estimated to be malnourished, and 90\% live in poverty, according to the United Nations. ${ }^{3}$ Around five million have fled the country's economic hardship, insecurity, and state oppression in the past few years.

Human rights groups say the empty shelves in the country's supermarkets are also commonplace in its hospitals, leaving the last line of defence against the pandemic frail.

"For years the health system in Venezuela has been collapsing, the lack of basic infrastructure and basic supplies to provide attention is part of day-to-day life,” says Erika Guevera Rosas, Amnesty International's Americas director.

In the midst of covid-19, around a third of Venezuela's hospitals have no access to potable water, while two thirds have only an intermittent supply, a Human Rights Watch survey found in late February. ${ }^{4}$ Over three quarters experienced shortages of soap and more lacked alcohol gel.

"They are responding with the little they have, sometimes buying their own supplies and treating people in their own houses,” Rosas says. "These healthcare workers are working in a context of conflict."

The shortages have left healthcare workers emotionally and physically overworked. More than 30 ooo have left the country in the past decade, according to the Venezuelan Medical Federation. ${ }^{5}$

In the capital, Caracas, $67 \%$ of hospitals have no face protection and $92 \%$ are reusing face coverings, according to Medicos Unidos de Venezuela. ${ }^{6}$ Doctors in rural hospitals are even more poorly equipped.

In the covid-19 wards in which the internist worked, she was given gowns that are washed and generic surgical masks instead of the more effective N95 models, but in other wards there was no PPE at all. "The state abandoned us, they don't care if we are there, if we aren't, if we live, or if we die," she says.

Adding to the risk caused by PPE shortages, hospitals lack basic training and protocols to combat the spread of the disease, says Jaime Lorenzo, director of Medicos Unidos. Most are not implementing one way 
walk systems, separating areas containing suspected cases of covid-19, or enforcing the use of PPE, he says.

"Most countries I have observed are implementing strict protocols," Lorenzo says. "In Caracas I have seen one hospital achieve this. And those that say they are, are not."

\section{Information war}

Over 3000 healthcare workers across 79 countries have lost their lives so far to covid-19, according to Amnesty International. Venezuela accounts for over 200 of those-among them doctors, nurses, immunologists, surgeons, and gynaecologists, according to Medicos Unidos.

President Maduro's government has managed the healthcare crisis in the same way it has managed previous crises: by trying to silence its critics. Maduro and his information minister have denied the PPE shortages, instead blaming healthcare workers for carelessness. ${ }^{7}$ The government contends that 12 healthcare workers have contracted the virus and died, not over 200.

Few take Venezuelan government information seriously. When it reported 1148 new covid-19 cases nationwide on 16 August, Amnesty International found that 691 patients were hospitalised with covid-19 symptoms in Caracas's main hospitals alone. Such disparities highlight the lack of truth in government claims, Amnesty says. ${ }^{8}$

Healthcare workers say the government has tried to tightly control the narrative surrounding the crisis by intimidating or arresting them, as happened to Andrea Sayago, a bioanalyst in the state of Trujillo. In early April, Sayago carried out tests on one of the first Venezuelan patients diagnosed with covid-19 and alerted colleagues. That day she was pressured by hospital directors to resign and publicly singled out by her local governor in social media for divulging classified information. The following day she was detained by Venezuela's intelligence service for 48 hours, accused of terrorism, and placed under house arrest, where she remained, prohibited from making any public declarations, until 31 August.

Amnesty's Guevara Rosas says the practice of firing healthcare workers who denounce poor working conditions has become increasingly common across Latin America during the pandemic. It has recorded such incidents in Chile, Mexico, Nicaragua, and Paraguay.

Venezuela, however, has surpassed them all by also detaining and prosecuting at least 12 healthcare workers in civil and military courts on accusations of conspiracy. The intimidation silenced healthcare workers and academics, say human rights advocacy groups. "No one wanted to report on the situation out of fear," says Marino Alvarado, a researcher at the Caracas based human rights group PROVEA.

PROVEA stopped publishing reports on the crisis from March to May fearing repercussions as growing numbers of healthcare workers and government critics were detained. The scarcity of information from non-government sources has made understanding the true picture inside the country's hospitals opaque.

But even risking being detained or jailed, the country's healthcare workers have refused to be silenced. Numerous Twitter accounts created by doctors-some anonymous but others not-have sprung up to tell the reality of the situation in their clinics and to call for assistance.

When in May a government official issued a threat on television to the coalition of academics, Integrantes de Academia de Fisica y Matematica, for publishing a report estimating that there would be
4000 daily cases of covid-19 by June, the academics replied firmly, doubling down on their research rather than backtracking. ${ }^{9}$

Since then the number of doctors, journalists, and human rights groups speaking out on conditions inside hospitals has surged, allowing a more accurate picture to emerge and assistance to arrive for those who need it most.

"The government was trying to monopolise the statistics but there were so many people reporting," says Alvarado, who believes the country's doctors have forced the government's hand. "They were going to have to jail too many people."

Though freedom of expression may have increased, Rosas is doubtful it will last. She questions the timing of the government seeming more tolerant just as the United Nations published a report finding Venezuela's security forces to have committed crimes against humanity. ${ }^{10}$ "We don't believe they are opening up and enabling people to denounce those who criticise the precarious conditions there," she said.

Competing interests: I have read and understood BMJ's policy on declaration of interests and have no relevant interests to declare.

Commissioning and peer review: Commissioned; not peer reviewed.

Medicos Unidos Venezuela. https://twitter.com/MedicosUnidosVe/status/1314664656951275520?s=20.

2 Pons C, Armas M. Venezuela's timid gains in taming inflation fade as food prices soar. Reuters. 2020 May 11. https://www.reuters.com/article/us-venezuela-economy-idUSKBN22N26A.

3 Associated Press. One in three Venezuelans not getting enough to eat. Guardian 2020 Feb 24 https://www.theguardian.com/world/2020/feb/24/venezuela-hungry-food-insecure-un-worldfood-program.

4 Human Rights Watch. Venezuela: urgent aid needed to combat covid-19. https://www.hrw.org/news/2020/05/26/venezuela-urgent-aid-needed-combat-covid-19.

5 Venezuelan Medical Federation. Más de 30.000 médicos se han ido de Venezuela [More than 30000 doctors have left Venezuela]. 12 Sep 2020. https://www.elimpulso.com/2019/09/12/fmv30-000-medicos-se-han-ido-de-venezuela-12sep.

6 Monitor Salud. https://twitter.com/MonitorSaludVE/status/1306393639141203968/photo/1.

7 Sarmiento M. Le responden a Maduro que el personal de salud se contagia por la falta de guantes y tapabocas. [Maduro is told that health personnel are infected by a lack of gloves and bottle caps.] Cronica Uno 2020 May 25. https://cronica.uno/responden-a-maduro-que-personal-desalud-se-contagia-por-falta-de-guantes.

8 Amnesty International. Venezuelan authorities are repressing and failing to protect health workers as COVID-19 gathers force. https://www.amnesty.org/en/latest/news/2020/08/venezuelan-authorities-are-repressing-and-failing-to-protect-health-workers-as-covid-19-gathers-force/

9 infobae. Diosdado Cabello ordenó perseguir a los científicos que alertaron sobre el impacto del coronavirus en Venezuela. [Diosdado Cabello ordered the persecution of scientists who warned of the impact of coronavirus on Venezuela. ] https://www.infobae.com/ameri-

ca/venezuela/2020/05/14/diosdado-cabello-ordeno-perseguir-a-los-cientificos-que-alertaronsobre-el-impacto-del-coronavirus-en-venezuela.

10 Nebehay S. Maduro security forces committed crimes against humanity. Reuters 2020 Sept 16. https://www.reuters.com/article/venezuela-security-un-idUSL8N2GC690.

This article is made freely available for use in accordance with BMJ's website terms and conditions for the duration of the covid-19 pandemic or until otherwise determined by BMJ. You may use, download and print the article for any lawful, non-commercial purpose (including text and data mining) provided that all copyright notices and trade marks are retained. 